\title{
TINGKAT ADOPSI VARIETAS INPARA DI LAHAN RAWA LEBAK
}

\author{
Yanti Rina dan Koesrini \\ Balai Penelitian Pertanian Lahan Rawa \\ E-mail: tuha13@yahoo.co.id
}

\begin{abstract}
Adoption was a process of behavior change either in the form of knowledge, attitudes and skills in a person in accepting innovation delivered by farming educator.The research objective was to determine the level of Inpara adoption in swampyland with information output of Inpara adoption varieties in swampylands.The research was conducted in swampyland on Tapin and Hulu Sungai Utara (HSU) district during February to May 2015.Total sample of 60 people selected randomly distributed in the six villages. Data were analyzed descriptively both qualitative and quantitative data with scoring techniques.Results showed that the level of Inpara adoption on swampyland remained low, i.e. 66.88\%/year on HSU district and ($74.56 \% / y e a r)$ on Tapin district.The low level of adoption was due to the selection of varieties that had been developed in swampland, namely Ciherang, Mekongga and some numbers Inpari adaptive and dissemination of varieties Inpara not widely distributed to swampyland area.Despite the level of knowledge of farmers on Inpara varieties was relatively high (68.3\%) and attitudes of farmers toward Inpara varieties innovation were classified agree (72.9\%), not yet ensure increased adoption of Inpara varieties in the two districts.
\end{abstract}

Keywords: Adoption, Inpara, swampyland

\begin{abstract}
Abstrak : Adopsi merupakan proses perubahan perilaku baik yang berupa pengetahuan, sikap maupun keterampilan pada diri seseorang dalam menerima inovasi yang disampaikan oleh penyuluh/mantri tani.Tujuan penelitian untuk mengetahui tingkat adopsi varietas Inpara di lahan rawa lebak dengan keluaran informasi adopsi varietas Inpara di lahan rawa lebak.Penelitian dilaksanakan di lahan rawa lebak di Kabupaten Tapin dan Hulu Sungai Utara pada musim tanam 2015. Jumlah sampel sebanyak 60 orang dipilih secara acak sederhana tersebar pada enam desa. Data dianalisis secara diskriptif baik data kualitatif maupun kuantitatif dengan teknik skoring. Hasil penelitian menunjukkan bahwa tingkat adopsi varietas Inpara di lahan rawa lebak masih rendah, yaitu 66,88\%/tahun di Kabupaten HSU dan (-74,56\%/tahun) di Kabupaten Tapin. Rendahnya tingkat adopsi ini disebabkan adanya pilihan varietas yang sudah berkembang di lahan rawa lebak, yaitu Ciherang, Mekongga dan beberapa nomor Inpari yang adaptif serta diseminasi varietas Inpara belum tersebar luas ke wilayah lebak. Meskipun tingkat pengetahuan petani terhadap varietas Inpara tergolong tinggi $(68,3 \%)$ dan sikap petani terhadap inovasi varietas Inpara tersebut tergolong setuju $(72,9 \%)$, belum menjamin peningkatan adopsi varietas Inpara di kedua kabupaten tersebut.
\end{abstract}

Kata kunci : adopsi, Inpara, lahan rawa lebak

\section{PENDAHULUAN}

Pengembangan padi ke lahan rawa lebak merupakan salah satu alternatif untuk mengantisipasi semakin berkurangnya lahan pertanian di Pulau Jawa akibat alih fungsi lahan ke lahan non pertanian. Luas lahan lebak di Indonesia mencapai sekitar 13,28 juta ha,yang berpotensi untuk lahan pertanian diperkirakan sekitar 2.337.152 ha, lahanyang sudah dibuka 
925.835 ha $(7 \%)$, sehingga yang belum dibuka sekitar 1.411.317 ha $(10,6 \%$ ) (Nugroho et al., 1992; Irianto, 2006).Lahan rawa lebak merupakan lahan dengan kesuburan tergolong sedang, karena setiap tahun lahan mendapat endapan lumpur dari daerah di kawasan hulu. Lahan rawa lebak juga memiliki keunggulan spesifik, yaitu dapat menghasilkan padi pada saat El-Nino, sementara agroekosistem lain (sawah irigasi dan tadah hujan) pada kondisi kekeringan (Nursyamsi et al., 2014).

Kabupaten Hulu Sungai Utara dan Tapin merupakan dua kabupaten yang memiliki potensi lahan rawa lebak yang cukup luas, yaitu 17.293 ha dan 10.498 ha (Wakhid dan Syahbudin, 2013). Tingkat produktivitas padi di kedua kabupaten tersebut cukup tinggi, yaitu 4-5 t/ha. Dua varietas dominan yang dikembangkan di kedua kabupaten tersebut adalah Ciherang dan Mekongga yang memiliki adaptasi dan hasil cukup tinggi.

Penanaman varietas yang sama secara terus menerus dapat menyebabkan peningkatan serangan hama penyakit dan ini terjadi pada kedua varietas tersebut yang rentan terhadap penyakit blas. Pergiliran varietas diperlukan untuk memutus siklus hama di lapangan. Inpara merupakan varietas yang dilepas untuk adaptasi di lahan rawa baik lahan rawa pasang surut dan lebak. Perkembangan varietas ini di lahan rawa lebak Kalimantan Selatan relatif masih rendah (BPSBTPH,2015). Permasalahan yang dihadapi dalam penggunaan varietas unggul baru adalah sistem informasi keberadaan varietas tersebut masih lemah, sehingga pengetahuan pengguna tentang varietas unggul baru masih rendah dan ketersediaan benih varietas unggul baru juga masih terbatas (Wahyuni, 2011). Salah satu upaya untuk meningkatkan adopsi teknologi dalam hal ini penggunaan varietas Inpara dilakukan melalui diseminasi ke petani berupa display varietas dan menyediakan benihnya.

Dalam rangka mendukung penyebaran varietas Inpara, UPBS padi rawa mendistribusikan benihyang dihasilkan melalui bantuan benih $(70 \%)$ baik ke lahan rawa pasang surut maupun lebak. Untuk mengetahui seberapa besar dampak bantuan benih ini terhadap pengembangan padi di lahan rawa, maka perlu dilakukan studi adopsi. Hasil studi adopsi di lahan rawa pasang surut dengan studi kasus di Kabupaten Barito Kuala menunjukkan bahwa adopsi varietas Inpara 2 dan 3 di kabupaten tersebut tergolong tinggi (Rina dan Koesrini, 2016), sedangkan untuk di lahan rawa lebak informasi tersebut masih belum ada.Adopsi merupakan proses perubahan perilaku baik yang berupa pengetahuan, sikapmaupun keterampilan pada diri seseorang dalam menerima inovasi yang disampaikan oleh penyuluh(Mardikanto, 1993). Tahapan proses adopsi meliputi (1) tahap kesadaran, (2) tahap minat, (3) tahap penilaian, (4) tahap mencoba, dan (5) tahap adopsi. Corner dan Hawthorn (1986) bahwa dengan melihat langsung suatu inovasi teknologi akan menimbulkan kepercayaan yang lebih besar. Faktor yang mendorong petani mengadopsi menggunakan varietas unggul baru adalah umur tanaman genjah, produktivitas lebih tinggi, ketahanan terhadap hama penyakit lebih baik, penampakan gabah lebih baik dan daya adaptasi baik (Sugandi dan Astuti, 2012). Adopsi varietas juga berhubungan dengan pemasaran. Varietas yang mudah dipasarkan akan memiliki tingkat adopsi yang lebih tinggi dibandingkan yang sulit dipasarkan.

Adopsi inovasi adalah proses yang dinamis yang terus berkembang dan dipengaruhi oleh berbagai faktor seperti (1) kondisi petani sendiri, (2) kondisi lingkungan, dan (3) karakteristik dari teknologi yang akan diadopsi. Oleh karena itu untuk mengetahui tingkat adopsi varietas baru padirawa, perlu dilihat sikap dan pengetahuan pengadopsi kemudian penerapannya. Tujuan penelitian untuk mengetahui tingkat adopsi varietas Inpara di lahan rawa lebak dengan keluaran informasi adopsi varietas Inpara di lahan rawa lebak.

\section{METODE PENELITIAN}

Penelitian ini dilakukan di lahan rawa lebak di KabupatenTapin dan Hulu Sungai Utaramulai bulan Februari sampai dengan Mei 2015 dengan menggunakan metode survei. Kegiatan dilaksanakan di dua desa pada dua kecamatan di Kabupaten Tapin, yaitu Desa Keramat Kecamatan Tapin Utara dan Desa Masta Kecamatan Bakarangan dan di empat desa pada dua kecamatan di Kabupaten Hulu Sungai Utara, yaitu di Desa Haur Gading dan Sungai Limas Kecamatan Haur Gading dan Desa Durait Tengah dan Durait Hilir Kecamatan Babirik. 
Jumlah sampel sebanyak 60 orang dipilih secara acak sederhana tersebar pada enam desa. Data yang dikumpulkan meliputi data primer dan data sekunder. Data pimer meliputi : (1) Karakteristik petani, (2) Sikap dan pengetahuan petani terhadap varietas Inpara, (3) Tingkat adopsi terhadap varietas Inpara.Data sekunder diperoleh dari Dinas Pertanian di kedua kabupaten tersebut, meliputi luas tanam di dua kabupaten tersebut pada periode tahun 20122014. Data primer dikumpukan dengan melakukan wawancara kepada petani terpilih menggunakan quisioner terstruktur, sedangkan data sekunder diperoleh dari Dinas Pertanian Tanaman Pangan dan Hortikultura Kabupaten Tapin dan Hulu Sungai Utara.

Metode Analisis. Data yang terkumpul ditabulasi kemudian dianalisis menggunakan teknik skoring dilakukan terhadap tingkat pengetahuan dan sikap petani (Tabel 1).

Tabel 1. Kategori tingkat pengetahuan dan sikap petani terhadap adopsi inovasi varietas Inpara di lahan rawa lebak

\begin{tabular}{ccc}
\hline $\begin{array}{c}\text { Interval skor } \\
(\%)\end{array}$ & Pengetahuan & Sikap \\
\hline$>84-100$ & Sangat tinggi & Sangat setuju \\
$>68-84$ & Tinggi & Setuju \\
$>52-68$ & Sedang & Ragu-Ragu \\
$>36-52$ & Rendah & Tidak Setuju \\
$>20-36$ & Sangat Rendah & Sangat tidak \\
& & setuju \\
\hline
\end{tabular}

Data perilaku petani didistribusikan pada kelas yang berbeda. Pemberian skor menggunakan skala Likert berjenjang lima (sikap dan pengetahuan). Kelas-kelas tersebut memiliki interval yang besarnya ditentukan melalui rumus interval kelas. Nilai skor ditampilkan dalam bentuk persentase (Nasution 1988; Suharyanto dan Kariada 2011) dengan rumus:

$$
\text { Panjang }=\frac{\% \text { Skor tertinggi }-\% \text { skor terendah }}{\text { interval Jumlah interval klas }}
$$

Tingkat adopsi varietas diukur menggunakan luas pertanaman varietas unggul Inpara. Perhitungan dilakukan pada saat mulai menanam (tahun dasar) selanjutnya pada tahun berikutnya. Untuk mengetahui peningkatan luas tanam dengan cara melihat pada hasil perbedaan (selisih) luas tanam tahun ke-n dengan luas tanam tahun dasar (sebelumnya) dibagi luas tanam tahun dasar (sebelumnya). Tingkat adopsi (\%) per tahun diperoleh dengan menjumlahkan peningkatan per tahun dibagi jumlah tahun dikali 100. Rata-rata adopsi varietas unggul merupakan rata-rata luas tanam per tahun.

Tingkat adopsi padi unggul:

Luas tanam tahun ke $\mathrm{n}$ - luas tanam sebelumnya

Luas tanam unggul tahun sebelumnya

\section{HASIL DAN PEMBAHASAN}

\section{Karakteristik Petani}

Karakteristik petani di kedua kabupaten disajikan pada Tabel 2. Umur petanirata-rata di lahan rawa lebak di lokasi penelitian 43,71tahun dan tergolong umur produktif. Umur petani rata-rata di lahan rawa lebak lebih muda dibandingkan umur petani rata-rata di lahan rawa pasang surut (47,37 tahun) (Rina dan Koesrini, 2016).

Tingkat pendidikan petani rata-rata di lahan rawa lebak 7,64 tahun (SMP), sama dengan tingkat pendidikan petani di lahan rawa pasang surut $(7,6)$ (Rina dan Koesrini, 2016). Artinya petani memiliki pendidikan yang cukup baik untuk menerima teknologi introduksi. Soekartawi (1988), menyatakan bahwa petani dengan pendidikan tinggi pada umumnya lebih cepat mengadopsi inovasi dibandingkan yang berpendidikan rendah. Prayogo (2010) juga menyatakan bahwa perbedaan tingkat penguasaan teknologi disebabkan oleh perbedaan atribut yang melekat pada diri petani seperti pengalaman usahatani, umur, pendidikan, dan juga disebabkan oleh faktor luar seperti penyuluhan.

Lama pengalaman berusaha tani rata-rata 21,05 tahun, dan dapat dijadikan sebagai faktor pendorong keberhasilan usahatani padi di lahan rawa lebak. Tenaga kerja produktif petani 3,52 orang/KK dengan kisaran 3-4 orang/KK. Luas kepemilikan lahan rata-rata seluas 1,46 $\mathrm{ha} / \mathrm{KK}$, sementara yang digarap $1,5 \mathrm{ha} / \mathrm{KK}$. Hal ini menunjukkan bahwa petani selain menggarap lahan sendiri juga mengerjakan lahan bukan miliknya. 
Yanti Rina Dan Koesrini : Tingkat Adopsi Varietas Inpara di ....

Tabel 2. Karakteristik petani Kabupaten Hulu Sungai Utara dan Tapin di lahan rawa lebak, tahun 2015

\begin{tabular}{|c|c|c|c|c|c|c|}
\hline \multirow[b]{2}{*}{ No } & \multirow[b]{2}{*}{ Uraian } & \multicolumn{2}{|r|}{ Kab.HSU } & \multicolumn{2}{|c|}{ Kab. Tapin } & \multirow[t]{2}{*}{ Rerata } \\
\hline & & Kec.Babirik & Kec.HaurGading & Kec.Bakarangan & $\begin{array}{l}\text { Kec.Tapin } \\
\text { Utara }\end{array}$ & \\
\hline 1. & Umur (th) & 43,47 & 46,00 & 41,47 & 43,93 & 43,71 \\
\hline 2. & Pendidikan (th) & 7,58 & 8,30 & 7,00 & 7,70 & 7,64 \\
\hline \multirow{2}{*}{$\begin{array}{l}3 . \\
4 .\end{array}$} & Pengalaman (th) & 14,65 & 26,54 & 21,27 & 21,73 & 21,05 \\
\hline & $\begin{array}{l}\text { Tenaga kerja } \\
\text { produktif } \\
\text { (org/KK) }\end{array}$ & 3,76 & 4,00 & 3,33 & 3,00 & 3,52 \\
\hline \multirow[t]{3}{*}{5} & $\begin{array}{l}\text { Pemilikan lahan } \\
\text { (ha) }\end{array}$ & 1,28 & 1,33 & 0,89 & 2,36 & 1,46 \\
\hline & Pekarangan & 0,13 & 0,33 & 0,19 & 0,16 & 0,20 \\
\hline & Sawah & 1,15 & 1,00 & 0,70 & 2,20 & 1,26 \\
\hline \multirow[t]{3}{*}{6.} & $\begin{array}{l}\text { Lahan garapan } \\
\text { (ha) }\end{array}$ & 1,35 & 1,06 & 1,13 & 2,48 & 1,50 \\
\hline & Pekarangan & 0,26 & 0,02 & 0,47 & 0,23 & 0,24 \\
\hline & Sawah & 1,09 & 1,04 & 0,66 & 2,25 & 1,26 \\
\hline
\end{tabular}

Sumber: data primer

Teknologi Budidaya Padi di Lahan Rawa Lebak

Petani pada umumnya sudah mengenal benih yang berkualitas (daya tumbuh tinggi dan murni) dengan membeli benih dari penangkar benih yang tersedia di kios. Varietas yang ditanam adalah varietas unggul Ciherang dan Mekongga. Persemaian akan dimulai apabila tinggi air $\pm 0,5$ meter. Pada saat umur bibit 5-7 hari setelah semai, bibit akan dipindah/ diampak hingga 20-30 hari kemudian ditanam. Penanaman dilakukan pada bulan Juni dan panen bulan September-Oktober.

Persiapan lahan untuk tanaman padi hanya pembersihan dari gulma dengan cara di kait pada saat air dalam atau ditebas kemudian dibiarkan di lahan untuk dijadikan mulsa. Sebagian petani melakukan pada saat air mulai surut sekitar bulan Maret dengan cara menggulung rumput atau "menandar" (bahasa daerah), kemudian diangkut ke galengan/ guludan. Jarak tanam padi tergantung dengan kedalaman air, pada watun 1 dan II $20 \mathrm{~cm}$, watun III 25-30 cm. Petani pada umumnya tidak menggunakan pupuk lengkap. Pupuk yang diberikan umumya hanya pupuk Urea dengan dosis rendah (50-100 kg/ha) yang diberikan 2-3 hari setelah tanam. Pemeliharaan seperti penyiangan jarang dilakukan. Pengairan diberikan 1-2 pada 1 musim pertanaman, yaitu dengan memompa air di sungai ke saluran sekunder dan primer
Panen padi dilakukan pada akhir bulan September hingga pertengahan Oktober, berlangsung hingga 6 minggu pada watun 1, II dan III. Jika padi masaknya terlambat, maka hasilnya sulit diharapkan karena biasanya akan diserang hama tikus. Panen padi dilakukan menggunakan sabit bergerigi. Tenaga pemanen melakukan pemotongan padi dan mengumpulkan di lahan sawah kemudian dirontok dengan mesin perontok dengan biaya Rp. 150-Rp. 200/kg GKP. Upah angkut gabah Rp. 150-Rp.200/kg GKP tergantung jarak. Gabah setelah diangkut ke rumah, dibersihkan dengan gumbaan (winnower=alat penampi) kemudian dikeringkan dan dibersihkan kembali dengan gumbaan, baru dimasukan ke dalam karung dan disimpan.

\section{Pengetahuan dan Sikap Petani}

Tingkat pengetahuan petani terhadap varietas Inpara 2 dan 3 tercantum pada Tabel 3. Tingkat pengetahuan petani Kabupaten Hulu Sungai Utara terhadap potensi hasil memperoleh nilai skor rata-rata tinggi, sedangkan di Kabupaten Tapin lebih rendah. Sebaliknya tingkat pengetahuan petani KabupatenTapin terhadap tinggi tanaman lebih tinggi dibandingkan petani Kabupaten Hulu Sungai Utara. Hal ini disebabkan pertanaman padi varietas Inpara di Kecamatan Bakarangan mengalami kebanjiran pada saat berbunga sehingga sebagian tanaman tidak menghasilkan dengan maksimal. 
Yanti Rina Dan Koesrini : Tingkat Adopsi Varietas Inpara di ....

Tabel 3.Tingkat pengetahuan petani terhadap karakteristik varietas Inpara di lahan rawa lebak Provinsi Kalimantan Selatan, tahun 2015

\begin{tabular}{|c|c|c|c|c|c|c|c|c|c|c|}
\hline \multirow{2}{*}{ No. } & \multirow{2}{*}{ Variabel } & \multicolumn{3}{|c|}{ Kab HSU (skor) } & \multicolumn{3}{|c|}{ Kab. Tapin(skor) } & \multirow{2}{*}{$\begin{array}{l}\text { Rerata } \\
\text { (skor) }\end{array}$} & \multirow{2}{*}{$\begin{array}{l}\text { Persen } \\
(\%)\end{array}$} & \multirow[t]{2}{*}{ Kategori } \\
\hline & & BRK & HAG & Rerata & TUT & BKG & Rerata & & & \\
\hline 1. & Varietas unggul & 3,8 & 3,7 & 3,75 & 2,8 & 3,2 & 3,00 & 3,375 & 67,5 & Sedang \\
\hline 2. & Potensi hasil tinggi & 4,0 & 3,9 & 3,95 & 2,7 & 3,2 & 2,95 & 3,450 & 69,0 & Tinggi \\
\hline 3. & $\begin{array}{ll}\text { Adaptif } & \text { dengan } \\
\text { lingkungan } & \end{array}$ & 4,2 & 3,5 & 3,85 & 2,7 & 3,3 & 3,00 & 3,425 & 68,5 & Tinggi \\
\hline 4. & $\begin{array}{l}\text { Umur } \\
\text { panjang/pendek }\end{array}$ & 3,8 & 3,9 & 3,85 & 2,9 & 3,4 & 3,15 & 3,500 & 70,0 & Tinggi \\
\hline 5. & Tinggi tanaman & 3,6 & 3,7 & 3,65 & 3,5 & 4,0 & 3,75 & 3,700 & 74,0 & Tinggi \\
\hline 6. & Tingkat kerebahan & 3,9 & 3,6 & 3,75 & 2,8 & 3,1 & 2,95 & 3,350 & 67,0 & sedang \\
\hline 7. & Tahan terhadap HP & 3,7 & 3,6 & 3,65 & 2,8 & 3,2 & 3,00 & 3,325 & 66,5 & sedang \\
\hline 8. & $\begin{array}{l}\text { Tingkat kerontokan } \\
\text { gabah }\end{array}$ & 3,1 & 4,2 & 3,65 & 3,3 & 3,3 & 3,30 & 3,475 & 69,5 & tinggi \\
\hline 9. & Bentuk gabah & 3,7 & 3,9 & 3,80 & 2,9 & 3,2 & 3,05 & 3,425 & 68,5 & tinggi \\
\hline 10. & Tekstur nasi & 3,8 & 3,3 & 3,55 & 3,1 & 2,9 & 3,00 & 3,275 & 65,5 & sedang \\
\hline 11. & Umur bibit $<21 \mathrm{hr}$ & 4,1 & 3,5 & 3,80 & 2,8 & 3,4 & 3,10 & 3,450 & 69,0 & tinggi \\
\hline 12. & $\begin{array}{l}\text { Pemupukan (dosis } \\
\text { pupuk) }\end{array}$ & 3,7 & 3,7 & 3,70 & 3,4 & 3,7 & 3,55 & 3,625 & 72,5 & tinggi \\
\hline 13. & Ketersediaan benih & 3,5 & 3,8 & 3,65 & 2,8 & 3,4 & 3,10 & 3,375 & 67,5 & sedang \\
\hline 14. & $\begin{array}{l}\text { Kebutuhan } \\
\text { konsumen }\end{array}$ & 4,1 & 3,0 & 3,55 & 2,3 & 3,1 & 2,70 & 3,125 & 62,5 & sedang \\
\hline & Rata-rata & 3,80 & 3,66 & 3,73 & 2,90 & 3,31 & 3,10 & 3,415 & 68,3 & tinggi \\
\hline
\end{tabular}

Ket : Persentase skor 20-36 dikategorikan sangat rendah, 36-52: rendah, $52-68:$ sedang, 68-84 : tinggi dan 84-100: sangat tinggi; BRK = Babirik, HAG= Haur Gading, $T U T=$ Tapin Utara, BKG= Bakarangan

Selanjutnya nilai skor pengetahuan petani dengan skor rendah di Kabupaten Hulu Sungai Utara adalah pada variabel kebutuhan konsumenpadavarietasInpara dan tekstur nasi, sedangkan di Kabupaten Tapin adalah kebutuhan konsumen dan tingkat kerebahan. Tingkat pengetahuan petani pada kebutuhan konsumen terhadap varietas Inpara rendah, karena beras Inpara belum dikenal dipasaran seperti halnya beras varietasCiherang.

Nilai skor rata-rata tingkat pengetahuan petani di dua kabupaten terhadap varietas Inpara termasuk kategori tinggi $(68,3 \%)$. Nilai skor rata-rata pengetahuan petani di Kabupaten Hulu Sungai Utara lebih tinggi dibandingkan nilai skor di Kabupaten Tapin. Hal ini disebabkan pengenalan petani terhadap varietas Inpara di Kabupaten Hulu Sungai Utara (tahun 2010) lebih dulu dibandingkan dengan di Kabupaten Tapin (tahun 2012). Namun luas tanam varietas Inpara yang tercatat di Diperta baru pada tahun 2012 di Kabupaten HSU dan tahun 2013 di Kabupaten Tapin.

Informasi dari penyuluh, petugas Diperta kabupaten dan informasi dari sesama petani merupakan faktor yang sangat menentukan tingkat pengetahuan petani tentang varietas tersebut. Nilai skor pengetahuan petani dalam kategori tinggi adalah: hasil varietas Inpara, adaptif dengan lingkungan, umur, tinggi tanaman, tingkat kerontokan gabah, bentuk gabah dan umur bibit. Secara keseluruhan tingkat pengetahuan petani terhadap adaptasi varietas Inpara 2 dan 3 terhadap lingkungan adalah tinggi sebesar 68,3. Hal ini disebabkan varietas Inpara sudah dicoba oleh petani dan memberikan hasil cukup tinggi. Adaptasi varietas Inpara 2 juga tergolong baik di lahan rawa lebak di Bengkulu dengan hasil 5,66 t/ha (Makruf et al., 2014).

Suatu individu akan membentuk sikap, setelah dia tahu tentang inovasi, maka tahap ini berlangsung setelah knowledge stage dalam proses keputusan inovasi. Rogers menyatakan bahwa knowledge stage lebih bersifat kognitif (tentang pengetahuan), sedangkan persuasion stage bersifat afektif karena menyangkut perasaan individu, karena itu pada tahap ini individu akan terlibat lebih jauh lagi. Sikap petani terhadap varietas Inpara di lahan rawa lebak termasuk kategori setuju dengan persentase 72,9\% (Tabel 4).

Sikap setuju petani terhadap varietas Inpara tertinggi pada produksi yang dicapai, karena petani telah mengetahui melalui kegiatan usahatani yang dilakukan maupun mendengar informasi dari sesama petani. Hal ini didukung dengan tingkat pengetahuan 
Yanti Rina Dan Koesrini : Tingkat Adopsi Varietas Inpara di ....

Tabel 4.Sikap petani terhadap karakteristik varietas Inpara di lahan rawa lebak Provinsi Kalimantan Selatan, tahun 2015

\begin{tabular}{|c|c|c|c|c|c|c|c|c|c|c|}
\hline \multirow[b]{2}{*}{ No. } & \multirow[b]{2}{*}{ Variabel } & \multicolumn{3}{|c|}{ Kab HSU (skor) } & \multicolumn{3}{|c|}{ Kab. Tapin(skor) } & \multirow[b]{2}{*}{$\begin{array}{l}\text { Rerata } \\
\text { (skor) }\end{array}$} & \multirow{2}{*}{$\begin{array}{c}\text { Persen } \\
(\%)\end{array}$} & \multirow{2}{*}{$\begin{array}{l}\text { Kate } \\
\text { gori }\end{array}$} \\
\hline & & $\begin{array}{c}\text { BR } \\
\text { K }\end{array}$ & $\begin{array}{c}\mathrm{HA} \\
\mathrm{G}\end{array}$ & Rerata & $\begin{array}{c}\mathrm{TU} \\
\mathrm{T}\end{array}$ & $\begin{array}{c}\text { BR } \\
\text { G }\end{array}$ & Rerata & & & \\
\hline 1. & Varietas unggul & 3,5 & 4,1 & 3,80 & 3,5 & 4,1 & 3,80 & 3,800 & 76,0 & setuju \\
\hline 2. & Manfaat hasil tinggi & 4,0 & 4,3 & 4,15 & 3,5 & 4,1 & 3,80 & 3,975 & 79,5 & setuju \\
\hline 3. & Adaptif dengan lingkungan & 3,9 & 4,0 & 3,95 & 3,5 & 3,8 & 3,65 & 3,800 & 76,0 & setuju \\
\hline 4. & Umur panjang/pendek & 3,5 & 4,1 & 3,80 & 3,4 & 3,7 & 3,55 & 3,675 & 73,5 & setuju \\
\hline 5. & Tinggi tanaman & 3,8 & 3,5 & 3,65 & 3,1 & 3,5 & 3,30 & 3,475 & 69,5 & setuju \\
\hline 6. & Tingkat kerebahan & 3,8 & 3,8 & 3,80 & 3,5 & 3,5 & 3,50 & 3,650 & 73,0 & setuju \\
\hline 7. & Tahan terhadap HP & 3,8 & 3,5 & 3,65 & 3,2 & 3,7 & 3,45 & 3,550 & 71,0 & setuju \\
\hline 8. & Tingkat kerontokan gabah & 3,6 & 3,6 & 3,60 & 3,7 & 3,4 & 3,55 & 3,575 & 71,5 & setuju \\
\hline 9. & Bentuk gabah & 3,7 & 3,6 & 3,65 & 3,1 & 3,9 & 3,50 & 3,575 & 71,5 & setuju \\
\hline 10. & Tekstur nasi & 3,5 & 3,4 & 3,45 & 3,4 & 3,4 & 3,40 & 3,425 & 68,5 & setuju \\
\hline 11. & Umur bibit $<21 \mathrm{hr}$ & 3,7 & 3,9 & 3,80 & 3,8 & 3,8 & 3,80 & 3,80 & 76,0 & setuju \\
\hline 12. & Pemupukan (dosis pupuk) & 3,8 & 3,5 & 3,65 & 3,9 & 3,9 & 3,90 & 3,775 & 75,5 & setuju \\
\hline 13. & Ketersediaan benih & 3,5 & 3,8 & 3,65 & 3,4 & 3,9 & 3,65 & 3,65 & 73,0 & setuju \\
\hline \multirow[t]{2}{*}{14.} & Kebutuhan konsumen & 3,8 & 3,7 & 3,75 & 3,3 & 3,4 & 3,35 & 3,55 & 71,0 & setuju \\
\hline & Rata-rata & 3,7 & 3,8 & 3,75 & 3,4 & 3,7 & 3,55 & 3,645 & 72,9 & setuju \\
\hline
\end{tabular}

Ket :Persentase skor 20-36= sangat tidak setuju; skor $>36-52=$ tidak setuju; skor $>52-68=$ ragu-ragu; Skor $>68$ $84=$ setuju dan skor $>84-100=$ sangat setuju; BRK = Babirik, HAG= Haur Gading, TUT=Tapin Utara, BKG= Bakarangan

Tabel 5. Proses adopsi varietas Inpara di lahan rawa lebak pada tahun 2015

\begin{tabular}{lcccccc}
\hline \multirow{2}{*}{ Kegiatan } & \multicolumn{2}{c}{ Kab. HSU } & \multicolumn{2}{c}{ Kab.Tapin } & \multicolumn{2}{c}{ Total } \\
\cline { 2 - 7 } & orang & $\%$ & Orang & $\%$ & orang & $\%$ \\
\hline $\begin{array}{l}\text { Mendengar langsung } \\
\text { menanam }\end{array}$ & 23 & 76,7 & 26 & 86,7 & 49 & 81,7 \\
$\begin{array}{l}\text { Menanam setelah } \\
\text { mendengar satu tahun }\end{array}$ & 4 & 13,3 & 4 & 13,3 & 8 & 13,3 \\
$\begin{array}{l}\text { Menanam setelah } \\
\text { mendengar dua tahun }\end{array}$ & 3 & 10,0 & - & - & 3 & 5,0 \\
\hline \multicolumn{1}{c}{ Total } & 30 & 100,0 & 30 & 100,0 & 60 & 100,0 \\
\hline
\end{tabular}

* Diolah dari lampiran 1 dan 2

petani yang tinggi terhadap karakteristik varietas tersebut. Kelebihan varietas Inpara adalah adaptif dengan lahan rawa lebak, bentuk gabah dan lebih tahan terhadap serangan hama penyakit blas sementara varietas unggul lainnya kurang tahan. Sikap petani terhadap kesesuaian varietas Inpara dengan lingkungan, petani menyatakan setuju. Terbentuknya sikap petani tidak secara otomatis karena jika seseorang mengambil keputusan untuk menerima atau menolak terhadap varietas tersebut, biasanya terdapat hubungan antara pengetahuan dan sikap. Ishak et al. (2016) menyatakan ada beberapa alas an utama petani mengadopsi varietas unggul antara lain rasa nasi disukai petani $(88,24 \%)$, produktivitas tinggi $(79,41 \%)$, harga jual tinggi, umur genjah, serta benih mudah diperoleh $(64,71 \%)$.

\section{Tingkat Adopsi Varietas Inpara}

Adopsi teknologi merupakan suatu proses mental dan perubahan perilaku baik berupa pengetahuan, sikap dan keterampilan sejak mendengar, mengenal hingga memutuskan untuk menerapkannya. Proses difusi teknologi tidak berbeda jauh dengan proses adopsi, namun dalam difusi sumber informasinya berasal dari sistem masyarakat itu sendiri, sedangkan adopsi sumber informasinya berasal dari luar sistem masyarakat tani (Roger dan Shoemaker, 1981). Sumber informasi berasal baik perorangan (tokoh masyarakat, sesama petani) maupun instansi (dinas pertanian, penyuluh, peneliti). Sebanyak $81,7 \%$ petani menyatakan bahwa pertama kali mendengar informasi tentang varietas Inpara dari PPL, sebesar 8,3\% dari kontak tani dan $10 \%$ sesame 
petani. Peran PPL cukup besar untuk memberikan informasi tentang varietas Inpara.

Proses adopsi teknologi memerlukan rentang waktu antara satu hingga tiga tahun, seperti dilaporkan oleh Hendayana et al. 2009 dalam Hendayana (2010). Petani yang mengadopsi varietas Inpara di lahan rawa lebak kurang dari satu tahun sebesar $81,7 \%$, setelah satu tahun $13,3 \%$ dan setelah dua tahun $5,0 \%$ (Tabel5).

Luas pertanaman varietas padi unggul di Kabupaten Hulu Sungai Utara tercantum pada Tabel 6. Varietas unggul yang berkembang di lahan lebak Kabupaten Hulu Sungai Utara sangat beragam, dan varietas yang memiliki luas tanam terluas pada tahun 2012-2014 adalah varietas Ciherang, Cibogo, dan Mekongga. Petani menyukai varietas Ciherang karena gabahnya lebih berat. Berat gabah varietas unggul rata-rata $10-11 \mathrm{~kg} / \mathrm{blek}$, sedangkan berat gabah varietas Ciherang 11-12 $\mathrm{kg} / \mathrm{blek}$.

Luas pertanaman varietas Inpara dibandingkan dengan luas tanam total padi unggul Kabupaten Hulu Sungai Utara sangat rendah, yaitu tahun 2012 sebesar $0,36 \%$, tahun 2013 sebesar $1,40 \%$ dan tahun 2014 sebesar $1 \%$ sehingga terjadi kenaikan sebesar $0,50 \%$ per tahun.

Tabel 6.Perkembangan luas tanam padi unggul di Kabupaten Hulu Sungai Utara, tahun 2012-2014

\begin{tabular}{|c|c|c|c|c|c|c|}
\hline \multirow[t]{2}{*}{ Varietas padi } & \multicolumn{2}{|c|}{2012} & \multicolumn{2}{|c|}{2013} & \multicolumn{2}{|c|}{2014} \\
\hline & $\begin{array}{l}\text { Luas tanam } \\
(\mathrm{Ha})\end{array}$ & $\%$ & $\begin{array}{l}\text { Luas tanam } \\
\text { (Ha) }\end{array}$ & $\%$ & $\begin{array}{l}\text { Luas tanam } \\
\text { (Ha) }\end{array}$ & $\%$ \\
\hline Ciherang & 17.364 & 72,76 & 5.896 & 58,88 & 15.453 & 64,10 \\
\hline Cibogo & 3.474 & 14,56 & 738 & 7,37 & 962 & 3,99 \\
\hline IR 66 & 758 & 3,18 & 347 & 3,47 & 457 & 1,90 \\
\hline Mekongga & 1.104 & 4,63 & 1.871 & 18,68 & 5.424 & 22,50 \\
\hline Batang Lembang & 455 & 1,91 & 264 & 2,64 & 570 & 2,36 \\
\hline PB42 & 265 & 1,11 & 475 & 4,74 & 234 & 0,97 \\
\hline Situ Bagendit & 25 & 0,10 & 47 & 0,46 & - & - \\
\hline Inpara 3 & 65 & 0,27 & 107 & 1,07 & 235 & 0,97 \\
\hline Inpara 4 & 22 & 0,09 & 31 & 0,31 & 7 & 0,03 \\
\hline Inpara 5 & - & - & 2 & 0,02 & - & - \\
\hline Inpari 4 & 2 & 0,01 & - & - & 122 & 0,51 \\
\hline Inpari 10 & 55 & 0,23 & - & - & 186 & 0,77 \\
\hline Inpari 13 & 182 & 0,76 & 22 & 0,22 & 51 & 0,21 \\
\hline Inpari 17 & - & - & 36 & 0,36 & 90 & 0,37 \\
\hline Inpari 19 & - & - & 3 & 0,03 & - & - \\
\hline Inpari 1 & 2 & 0,01 & - & - & - & - \\
\hline Inpago 3 & 11 & 0,05 & - & - & - & - \\
\hline Situ Patenggang & 1 & 0,00 & - & - & 1 & 0,004 \\
\hline Cisokan kuning & 79 & 0,33 & 38 & 0,34 & 11 & 0,045 \\
\hline Margasari & - & - & 1 & 0,01 & - & - \\
\hline Cisokan & - & - & 136 & 1,46 & 304 & 1,26 \\
\hline Total & 23.864 & 100,00 & 10.014 & 100,00 & 24.995 & 100,00 \\
\hline
\end{tabular}

Sumber :Diperta Kab HSU, 2015 Keterangan= tanda - tidak ada pertanaman

Tabel 7. Perkembangan luas tanam varietas Inpara di Kabupaten Hulu Sungai Utara, tahun 2012 - 2014

\begin{tabular}{lccccc}
\hline Tahun & $\begin{array}{c}\text { Inpara 3 } \\
\text { (ha) }\end{array}$ & $\begin{array}{c}\text { Inpara 4 } \\
\text { (ha) }\end{array}$ & $\begin{array}{c}\text { Inpara5 } \\
\text { (ha) }\end{array}$ & $\begin{array}{c}\text { Total } \\
\text { (ha) }\end{array}$ & $\begin{array}{c}\text { Perkembangan } \\
(\%)\end{array}$ \\
\hline 2012 & 65 & 22 & - & 87 & - \\
2013 & 107 & 31 & 2 & 140 & 60,92 \\
2014 & 235 & 7 & - & 242 & 72,85 \\
\hline Rerata/tahun & \multicolumn{7}{r}{} & 66,88 \\
\hline
\end{tabular}

Keterangan: tanda - tidak ada pertanaman 
Yanti Rina Dan Koesrini : Tingkat Adopsi Varietas Inpara di ....

Tabel 8. Perkembangan luas tanam padi unggul di KabupatenTapin, tahun 2012-2014

\begin{tabular}{lcccccc}
\hline Varietas padi & \multicolumn{2}{c}{2012} & \multicolumn{2}{c}{2013} & \multicolumn{2}{c}{2014} \\
\cline { 2 - 7 } & $\begin{array}{c}\text { Luas tanam } \\
\text { (Ha) }\end{array}$ & Persentase & $\begin{array}{c}\text { Luas tanam } \\
\text { (Ha) }\end{array}$ & $\begin{array}{c}\text { Persentase } \\
\text { Luas tanam } \\
(\text { Ha) }\end{array}$ & $\begin{array}{c}\text { Persen } \\
\text { tase }\end{array}$ \\
\hline PB42 & 3.851 & 12,17 & 255 & 3,18 & 294 & 7,46 \\
IR 66 & - & - & 580 & 7,24 & - & - \\
Inpari 7 & 41 & 0,13 & 48 & 0,60 & - & - \\
Inpari 8 & - & - & 20 & 0,25 & - & - \\
Inpari 9 & 1.064 & 3,36 & 85 & 1,06 & - & - \\
Inpari 10 & - & - & - & - & - & - \\
Inpari 11 & 100 & 0,32 & - & - & - & - \\
Inpari 12 & 1.567 & 4,95 & 35 & 0,44 & - & - \\
Inpari 13 & 1.583 & 5,00 & 209 & 2,61 & - & - \\
Inpara 2 & - & - & 140 & 1,75 & 80 & 0,75 \\
Inpara 3 & - & - & 609 & 7,60 & 124 & 1,17 \\
Inpara 4 & - & - & 18 & 0,22 & - & - \\
Inpara 5 & - & - & 35 & 0,44 & - & - \\
Ciherang & 13.875 & 43,84 & 5.211 & 65,06 & 7.528 & 70,77 \\
Mekongga & 8.156 & 25,77 & 740 & 9,24 & 1.726 & 16,23 \\
Batang Piaman & 211 & 0,67 & - & - & - & - \\
Situ Begendit & 974 & 3,08 & 25 & 0,31 & - & - \\
Inpago 6 & 226 & 0,71 & - & - & - & - \\
Cibogo & - & - & - & - & 127 & 1,19 \\
Buyung & - & - & - & - & 259 & 2,43 \\
\hline Total & 31.648 & 100,00 & 8.010 & 100,00 & 10.638 & 100,00 \\
\hline
\end{tabular}

Sumber :Diperta Kab HSU, 2015 Keterangan: tanda - tidak ada pertanaman

Tabel 9.Perkembangan luas tanam varietas Inpara di Kabupaten Tapin

\begin{tabular}{ccccccc}
\hline Tahun & $\begin{array}{c}\text { Inpara 2 } \\
\text { (ha) }\end{array}$ & $\begin{array}{c}\text { Inpara 3 } \\
\text { (ha) }\end{array}$ & $\begin{array}{c}\text { Inpara 4 } \\
\text { (ha) }\end{array}$ & $\begin{array}{c}\text { Inpara5 } \\
\text { (ha) }\end{array}$ & $\begin{array}{c}\text { Total } \\
\text { (ha) }\end{array}$ & $\begin{array}{c}\text { Perkem } \\
\text { bangan(\%) }\end{array}$ \\
\hline 2013 & 140 & 609 & 18 & 35 & 802 & - \\
2014 & 80 & 124 & - & - & 204 & $(74,56)$ \\
\hline Rerata/tahun & & & & & $(74,56)$ \\
\hline
\end{tabular}

Sumber: DipertaKab. Tapin, 2015. Keterangan: tanda - tidak ada pertanaman

Perkembangan luas tanam varietas Inpara di Kabupaten Hulu Sungai Utara tahun 2012-2014 tercantum pada Tabel 7. Dari Tabel tersebut menunjukkan bahwa terjadi peningkatan rata-rata $77 \mathrm{ha} /$ tahun atau sebesar $66,88 \% /$ tahun.

Luas tanam varietas Inpara di Kabupaten Tapin dibandingkan dengan luas tanam varietas unggul lainnya tercantum pada Tabel 8 . Luas tanam varietas Inpara pada tahun 2013 sebesar 10,01\% dan pada tahun 2014 hanya sebesar $1,92 \%$. Terjadi penurunan sebesar $8,09 \%$. Varietas yang ditanam secara meluas oleh petani adalah Ciherang dan Mekongga, sedangkan di Kabupaten Tapin luas pertanaman tidak tercatat sehingga data yang dihitung dari tahun 2013. Luas pertanaman Inpara tahun 2013 seluas 802 ha kemudian tahun 2014 seluas204 ha sehingga terjadi penurunan sebesar 74,56 \%, hal ini menurut petani karena sebagian tanaman padi rusak kena banjir.

Rendahnya adopsi varietas Inpara 2 dan 3 di lahan rawa lebak, disebabkan pilihan varietas di lahan tersebut cukup banyak, antara lain Ciherang dan Mekongga, sehingga varietas Inpara belum bisa berkembang di lahan rawa lebak. Selain itu diseminasi varietas Inpara juga masih terbatas. Sebaliknya di lahan rawa pasang surut, adopsi varietas Inpara 2 dan 3 tergolong tinggi. Tingginya adopsi varietas Inpara 2 dan 3 di lahan rawa pasang surut, karena pilihan varietas adaptif di lahan tersebut sangat terbatas. Ciherang dan Mekongga yang mendominasi pertanaman padi di Kalimantan Selatan, adaptasinya di lahan rawa pasang surut kurang baik. Koesrini dan Saleh (2015) 
melaporkan bahwa varietas Inpara 2 dan 3 berproduksi $31,7 \%$ lebih tinggi dibandingkan varietas Ciherang.

\section{KESIMPULAN}

Hasil penelitian menunjukkan bahwa tingkat adopsi varietas Inpara di lahan rawa lebak masih rendah, yaitu 66,88\%/tahun di Kabupaten HSU dan (-74,56\%/tahun) di Kabupaten Tapin. Rendahnya tingkat adopsi ini disebabkan adanya pilihan varietas yang sudah berkembang di lahan rawa lebak, yaitu Ciherang, Mekongga dan beberapa nomor Inpari yang adaptif serta diseminasi varietas Inpara belum tersebar luas ke wilayah lebak dan pertanaman mengalami kebanjiran. Meskipun tingkat pengetahuan petani terhadap varietas Inpara tergolong tinggi $(68,3 \%)$ dan sikap petani terhadap inovasi varietas Inpara tersebut tergolong setuju (72,9\%), belum menjamin peningkatan adopsi varietas Inpara di kedua kabupaten tersebut.

\section{SARAN}

1. Diseminasi varietas Inpara perlu lebih ditingkatkan di lahan rawa lebak, baik melalui demontrasi lapang/plot maupun uji preferensi varietas Inpara

2. Ketersediaan benih varietas Inpara perlu ditingkatkan sehingga petani dapat dengan mudah untuk memperoleh benihnya.

3. Meningkatkan penyuluhan tentang budidaya padi unggul di lahan rawa lebak

\section{DAFTAR PUSTAKA}

BPSBTPH. 2015. Informasi Benih Bersertifikat dari Penangkar di Kalimantan Selatan. Laporan Bulanan BPSBTPH Propinsi Kalimantan Selatan.

Corner and J. Hawthorn. 1986. Perception Interative Behavior Visual Communication Dalam "Comunication Studies" An Introduction Reader, 2nd ed Edward Arnold. 3 East Read Street, Baltimore. Maryland 21202. USA.

Dinas Pertanian Tanaman Pangan dan Hortikultura Kabupaten HSU. 2015. Laporan Tahunan Dinas Pertanian
Tanaman Pangan dan Hortikultura Kabupaten Hulu Sungai Utara Tahun 2015.

Dinas Pertanian Tanaman Pangan dan Hortikultura Kabupaten Tapin.2015. Laporan Tahunan Dinas Pertanian Tanaman Pangan dan Hortikultura Kabupaten Tapin Tahun 2015.

Hendayana, R. 2010. Pengkajian Strategi Percepatan Adopsi Varietas Padi Unggul di Lokasi Pasang Surut dan Rawa untuk Meningkatkan 200\% Adopter di Kalimantan Selatan dan Kalimantan Tengah. Laporan Hasil Penelitian Ristek. BBSDLP. 95 hal.

Ishak,A.,Dedi, S., dan Miswarti. 2016. Adopsi petani padi sawah terhadap varietas unggul padi di Kecamatan Argamakmur Kabupaten Bengkulu Utara, Provinsi Bengkulu

(Bengkulu.litbang.pertanian.go.id/ind/im ages/dokumen/publikasi/Adopsi petani padi BU.pdf) diakses 29 Juni 2016.

Irianto, G. 2006. Kebijakan dan Pengelolaan Air dalam Pengembangan Lahan Rawa Lebak. Prosiding Seminar Nasional Pengelolaan Lahan Rawa Terpadu, 28-29 Juli 2006. Balittra. Banjarbaru. Hlm: 920

Koesrini dan M. Saleh. 2015. Uji Adaptasi Varietas Inpara di Lahan Rawa Pasang Surut. Laporan Hasil Penelitian Balittra.

Mardikanto,T.1993.Penyuluhan Pembangunan Pertanian. Sebelas Maret University Press. Solo.

Makruf, E., Nurmegawati dan T. Wahyu. 2014. Adaptasi Varietas Unggul Baru Inpara 2 di Kabupaten Seluma Propinsi Bengkulu. Prosiding Seminar Nasional Sains dan Teknologi $V$ Lembaga Penelitian Universias Lampung, 19-20 November 2013.

Nasution, A.H. dan Barizi. 1988. Metode Statistika. Gramedia. Jakarta. 
Nursyamsi, D., M. Alwi, M. Noor, K. Anwar, E. Matfuah, I. Khairullah, I. Ar-Riza, S. Raihan, R.S. Simatupang, Norginayuwati Dan A. Jumberi. 2014b. Pengelolaan Lahan Rawa Lebak untuk Pertanian Berkelanjutan (Buku Pedum). IAARD Press. Badan Penelitian dan Pengembangan Pertanian.

Nugroho K.,Alkasuma, Paidi, Abdurachman, Wahyu Wahdini dan H. Suhardjo. 1992. Peta Sebaran dan kendala dan Arahan Pengembangan Lahan Pasang Surut, Rawa dan Pantai Seluruh Indonesia Skala 1:500.000. Bogor. Pusat Penelitian Tanah dan Agroklimat

Prayogo, A. 2010. Produktivitas dan Efisiensi Teknis Usahatani Padi Organik Lahan Sawah. Jurnal Agro Ekonomi 28(1):1-9.

Rina, Y. dan Koesrini. 2016. Tingkat Adopsi Varietas Inpara dan Margasari di Lahan Rawa Pasang Surut. Jurnal Agros 18(1):65-80.

Roger, E.M. dan F. Floyd Shoemaker. 1981. Memasyarakatkan Ide-ide Baru. Disarikan oleh Abdilah Hanafi. Penerbit Usaha Nasional. Surabaya.

Soekartawi. 1988. Prinsip Dasar Komunikasi Pertanian. UI-Press. Jakarta. 137 Hal.
Sugandi, D dan U.P. Astuti. 2012. Faktor yang mempengaruhi persepsi petani terhadap VUB padi sawah di Provinsi Bengkulu. Prosiding Seminar Nasional Inovasi Teknologi Pertanian Spesifik Lokasi, Bogor 19-20 Nopember 2011. Dalam Darman M. Arsyad et al (Penyunting) Balai Besar Pengkajian dan Pengembangan Teknologi Pertanian. Badan Litbang Pertanian.

Suharyanto dan I Ketut Kariada. 2011. Kajian Adopsi Penerapan Teknologi Pupuk Organik Kascing Di Daerah Sentra Produksi Sayuran Kabupaten Tabanan. Jurnal Pengkajian dan Pengembangan Teknologi Pertanian 14 (1): 28-39.

Sri Wahyuni. 2011. Teknik Produksi Benih Sumber Padi. Makalah disampaikan dalam Workshop Evaluasi Kegiatan Pendampingan SL-PTT 2011 dan Koordinasi UPBS 2012 tanggal 28-29 November 2011. Balai Besar Penelitian Padi. Tidak di publikasikan.

Wakhid, N. dan H. Syahbuddin. 2013. Peta Kalender Tanam Padi Lahan Rawa Lebak di Kalimantan Selatan di Tengah Perubahan Iklim Global. Jurnal IlmuGeometrika19 (1):32-39. 
Yanti Rina Dan Koesrini : Tingkat Adopsi Varietas Inpara di ....

Lampiran 1.Interval waktu sejak mulai mendengar/mengenal inovasi varietas Inpara sampai menerapkannya oleh petani Kab. HSU, 2015

\begin{tabular}{|c|c|c|c|c|c|}
\hline Lokasi & $\begin{array}{c}\text { Waktu } \\
\text { mendengar }\end{array}$ & $\begin{array}{c}\text { Waktu } \\
\text { Menerapkan }\end{array}$ & $\begin{array}{l}\text { Interval waktu } \\
\text { menerapkan (th) }\end{array}$ & $\begin{array}{l}\text { Jumlah } \\
\text { (orang) }\end{array}$ & Jumlah (\%) \\
\hline \multirow[t]{15}{*}{ Kec. Babirik } & 2010 & 2010 & 0 & 1 & 3,33 \\
\hline & & 2011 & - & - & \\
\hline & & 2012 & 2 & 2 & 6,67 \\
\hline & & 2013 & - & - & - \\
\hline & & 2014 & - & - & - \\
\hline & 2011 & 2011 & - & - & - \\
\hline & & 2012 & 1 & 4 & 13,34 \\
\hline & & 2013 & - & - & - \\
\hline & & 2014 & - & - & - \\
\hline & 2012 & 2012 & 0 & 7 & 23,33 \\
\hline & & 2013 & - & - & - \\
\hline & & 2014 & - & - & - \\
\hline & 2013 & 2013 & - & - & - \\
\hline & & 2014 & - & - & - \\
\hline & 2014 & 2014 & 0 & 3 & 10,00 \\
\hline \multirow{6}{*}{$\begin{array}{l}\text { Kec. Haur } \\
\text { Gading }\end{array}$} & 2012 & 2012 & 0 & 3 & 10,00 \\
\hline & & 2013 & - & - & - \\
\hline & & 2014 & 2 & 1 & 3,33 \\
\hline & 2013 & 2013 & 0 & 4 & 13,33 \\
\hline & & 2014 & - & - & - \\
\hline & 2014 & 2014 & 0 & 5 & 16,67 \\
\hline Total & & & & 30 & 100,00 \\
\hline
\end{tabular}


Lampiran 2.Interval waktu sejak mulai mendengar/mengenal inovasi varietas Inpara sampai menerapkannya oleh petani Kab. Tapin, 2015

\begin{tabular}{lccccc}
\hline \multicolumn{1}{c}{ Lokasi } & $\begin{array}{c}\text { Waktu } \\
\text { mendengar }\end{array}$ & $\begin{array}{c}\text { Waktu } \\
\text { Menerapkan }\end{array}$ & $\begin{array}{c}\text { Interval waktu } \\
\text { menerapkan (th) }\end{array}$ & $\begin{array}{c}\text { Jumlah } \\
\text { (orang) }\end{array}$ & $\begin{array}{c}\text { Jumlah } \\
(\%)\end{array}$ \\
\hline Kec. Tapin & 2013 & 2013 & 0 & 13 & 43,33 \\
Utara & & 2014 & 1 & 2 & 6,67 \\
Kec. & 2012 & 2012 & 0 & 2 & 6,67 \\
Bakarangan & & 2013 & 1 & 2 & 6,67 \\
& & 2014 & - & - & - \\
& 2013 & 2013 & 0 & 1 & 3,33 \\
& 2014 & - & - & - \\
& 2014 & 2014 & 0 & 10 & 33,33 \\
\hline Total & & & & 30 & 100,00 \\
\hline
\end{tabular}

